\title{
LIQUIDITY, SENTIMENT AND SEGMENTATION: A SURVEY OF CLOSED-END FUND LITERATURE
}

\author{
Mary FLETCHER ${ }^{1}$ \\ University of Strathclyde, Glasgow
}

\begin{abstract}
Closed-end funds have been a topic of lively debate for several decades. In this paper I focus on studies relating to liquidity, sentiment and segmentation and, in particular, on studies that investigate closedend country funds. I extend the previous survey by Dimson \& MinioKozerski (1999) by adding in more recent contributions to the closedend fund debate; and by including more of a discussion of sentiment, segmentation and country funds I complement the recent survey by Cherkes (2012). In addition I provide summaries of over 40 key papers in these areas, listing the sample and sample period, the theory examined and the findings of each paper.

8 Closed-end Fund; Closed-end Country Fund; Investment Trust; International Finance; International Financial Markets; Liberalization
\end{abstract}

JEL code: $G 12, G 15, G 23, F 3$

\section{INTRODUCTION}

Closed-end funds (known as investment trusts in the UK) were one of the first specialist financial intermediaries set up over a hundred years ago with the aim of giving the small investor access to a managed diversified portfolio. Closed-end funds are like mutual funds, insurance and pension funds in that they pool investor cash and invest it in the domestic or foreign stock or bond market. They are unlike mutual funds, insurance and pension funds in that they are public limited companies and are listed on stock exchanges.

\footnotetext{
${ }^{1}$ Correspondence address: Department of Accounting \& Finance, University of Strathclyde, Curran Building, 100 Cathedral Street, Glasgow, G4 0LN, United Kingdom; Tel: (+44) 141548 5794; Fax: (+44) 141552 3547; Email: m.h.fletcher@strath.ac.uk
} 
Another particular feature of closed-end funds that distinguishes them from other investment funds is their pricing structure. Whereas the price of most investment funds directly reflects the value of the individual fund's portfolio of assets, the closed-end fund Net Asset Value (NAV) ${ }^{1}$ usually differs continually from the stock market share price. As the closed-end fund share price is usually below the net asset value, this creates the characteristic closed-end fund discount or negative premium. $^{2}$ There has been much debate as to the causes and behavior of the premium, as it appears to violate the law of one price in which assets of the same value should trade for the same price.

Researchers have debated whether the fluctuating closed-end fund premium is due to irrational investor decisions based on sentiment, or to rational investor decisions based on market features such as liquidity and information asymmetries between markets. This survey summarizes the debate in these three areas.

\section{SENTIMENT-BASED EXPLANATIONS}

Table 1 below summarizes the findings of key papers on sentiment and closed-end funds.

\section{Table 1. Sentiment Studies}

\begin{tabular}{|c|c|c|c|c|c|}
\hline Author & $\begin{array}{c}\text { Sample } \\
\text { origin }\end{array}$ & $\begin{array}{c}\text { Sample } \\
\text { size }\end{array}$ & $\begin{array}{c}\text { Sample } \\
\text { period }\end{array}$ & $\begin{array}{c}\text { Explanation } \\
\text { examined }\end{array}$ & $\begin{array}{c}\text { Findings } \\
\text { confirmatory }\end{array}$ \\
\hline $\begin{array}{l}\text { De Long, } \\
\text { Shleifer et al. } \\
(1990)\end{array}$ & $\begin{array}{l}\text { Theoretical } \\
\text { paper }\end{array}$ & & & $\begin{array}{l}\text { Noise trader risk } \\
\text { posed by small } \\
\text { investors is } \\
\text { systematic and } \\
\text { means that } \\
\text { sophisticated } \\
\text { investors will only } \\
\text { buy at discount. } \\
\text { Arbitrage } \\
\text { prevented because } \\
\text { of short horizons } \\
\text { (i.e. not holding } \\
\text { until open-ending). }\end{array}$ & \\
\hline Lee et al. (1991) & US & $\begin{array}{l}20 \text { equity } \\
\text { funds. } \\
\text { Usually } \\
10 \text { in } \\
\text { index }\end{array}$ & 1956-1985 & $\begin{array}{l}\text { Application of } \\
\text { model developed } \\
\text { by De Long et al. } \\
\text { Discount is driven } \\
\text { by small investor } \\
\text { sentiment. } \\
\text { Discounts move } \\
\text { together. Funds } \\
\text { begin at times of }\end{array}$ & $\begin{array}{l}\text { Partial support. } \\
\text { Small r-square } \\
\text { and second } \\
\text { period not } \\
\text { significant }\end{array}$ \\
\hline
\end{tabular}

Vol. 12, No. 4 


\begin{tabular}{|c|c|c|c|c|c|}
\hline Author & $\begin{array}{c}\text { Sample } \\
\text { origin }\end{array}$ & $\begin{array}{c}\text { Sample } \\
\text { size }\end{array}$ & $\begin{array}{c}\text { Sample } \\
\text { period }\end{array}$ & $\begin{array}{c}\text { Explanation } \\
\text { examined }\end{array}$ & $\begin{array}{c}\text { Findings } \\
\text { confirmatory }\end{array}$ \\
\hline & & & & $\begin{array}{l}\text { positive investor } \\
\text { sentiment. } \\
\text { Discount changes } \\
\text { relate to small } \\
\text { stock returns. }\end{array}$ & \\
\hline Brauer (1993) & US & \begin{tabular}{|l|} 
Same \\
sample as \\
Lee et al. \\
1991
\end{tabular} & & $\begin{array}{l}\text { Noise trading only } \\
\text { accounts for small } \\
\text { percentage of } \\
\text { discount when } \\
\text { measured using } \\
\text { French \& Roll } \\
\text { (1986) signal } \\
\text { extraction } \\
\text { technique. Noise } \\
\text { trading occurs } \\
\text { across all stocks, } \\
\text { not just small } \\
\text { stocks }\end{array}$ & Yes \\
\hline $\begin{array}{l}\text { Hardouveliset al. } \\
(1994)\end{array}$ & US & $\begin{array}{l}35 \\
\text { country } \\
\text { funds }\end{array}$ & 1985-1993 & $\begin{array}{l}\text { Sentiment moves } \\
\text { the discount. } \\
\text { Sentiment } \\
\text { influences the IPO. } \\
\text { Country restrictions } \\
\text { influence premium }\end{array}$ & $\begin{array}{l}\text { Yes, IPOs } \\
\text { issued at } \\
\text { premium which } \\
\text { then mean- } \\
\text { reverts. No, } \\
\text { country } \\
\text { restrictions } \\
\text { don't influence } \\
\text { premium }\end{array}$ \\
\hline $\begin{array}{l}\text { Bodurtha et al. } \\
(1995)\end{array}$ & US & $\begin{array}{l}35 \\
\text { country } \\
\text { funds }\end{array}$ & 1986-1990 & $\begin{array}{l}\text { Sentiment drives } \\
\text { the premium. } \\
\text { Premium changes } \\
\text { correlate positively } \\
\text { with those on small } \\
\text { funds. Premiums } \\
\text { move together. } \\
\text { Fund premium } \\
\text { index correlates to } \\
\text { returns on small } \\
\text { investor held stocks } \\
\end{array}$ & $\begin{array}{l}\text { Yes. Finds } \\
\text { premium and } \\
\text { share price } \\
\text { move with US } \\
\text { market } \\
\text { sentiment, not } \\
\text { foreign market } \\
\text { sentiment. }\end{array}$ \\
\hline $\begin{array}{l}\text { Swaminathan } \\
(1996)\end{array}$ & US & \begin{tabular}{|l|} 
Same \\
closed- \\
end funds \\
as Lee, \\
Shleifer \\
\& Thaler \\
1991. \\
\end{tabular} & $1965-1990$ & $\begin{array}{l}\text { Sentiment does not } \\
\text { explain the } \\
\text { discount. Discounts } \\
\text { contain information } \\
\text { about future } \\
\text { expected earnings } \\
\text { growth and }\end{array}$ & $\begin{array}{l}\text { Yes. Refutes } \\
\text { Lee, Shleifer \& } \\
\text { Thaler } 1991\end{array}$ \\
\hline
\end{tabular}


Liquidity, sentiment and segmentation: a survey of closed-end fund literature

\begin{tabular}{|c|c|c|c|c|c|}
\hline Author & $\begin{array}{c}\text { Sample } \\
\text { origin }\end{array}$ & $\begin{array}{c}\text { Sample } \\
\text { size }\end{array}$ & $\begin{array}{c}\text { Sample } \\
\text { period }\end{array}$ & $\begin{array}{c}\text { Explanation } \\
\text { examined }\end{array}$ & $\begin{array}{c}\text { Findings } \\
\text { confirmatory }\end{array}$ \\
\hline & & $\begin{array}{l}\text { NYSE } \\
\text { stock } \\
\text { returns }\end{array}$ & & inflation & \\
\hline $\begin{array}{l}\text { Elton et al. } \\
(1998)\end{array}$ & US & $\begin{array}{l}32 \text { stock } \\
\text { funds } 38 \\
\text { bond } \\
\text { funds. } \\
\text { US } \\
\text { stocks }\end{array}$ & 1969-1994 & $\begin{array}{l}\text { Sentiment as } \\
\text { measured by } \\
\text { changes in discount } \\
\text { is not important } \\
\text { factor in generating } \\
\text { stock returns. } \\
\text { Discount is due to } \\
\text { negative alpha. }\end{array}$ & $\begin{array}{l}\text { Yes. Refutes } \\
\text { Lee, Shleifer \& } \\
\text { Thaler } 1991\end{array}$ \\
\hline $\begin{array}{l}\text { Klibanoff et al. } \\
(1998)\end{array}$ & US & $\begin{array}{l}39 \\
\text { country } \\
\text { funds }\end{array}$ & 1986-1994 & $\begin{array}{l}\text { Relative } \\
\text { prominence of } \\
\text { news affects } \\
\text { investor reaction } \\
\text { and affects } \\
\text { discount }\end{array}$ & Yes \\
\hline Brown (1999) & US & $\begin{array}{l}16 \\
\text { domestic } \\
\text { diversifie } \\
\text { d funds }\end{array}$ & 1993-1994 & $\begin{array}{l}\text { Greater closed-end } \\
\text { fund volatility is } \\
\text { associated with } \\
\text { increased levels of } \\
\text { sentiment }\end{array}$ & $\begin{array}{l}\text { Yes. Supports } \\
\text { Lee, Shleifer \& } \\
\text { Thaler } 1991\end{array}$ \\
\hline $\begin{array}{l}\text { Grullon \& Wang } \\
(2001)\end{array}$ & US & $\begin{array}{l}34 \text { US } \\
\text { equity } \\
\text { funds }\end{array}$ & $1982-1998$ & $\begin{array}{l}\text { Information } \\
\text { differential } \\
\text { between informed } \\
\text { and uninformed } \\
\text { investors drives the } \\
\text { discount. Informed } \\
\text { investors will only } \\
\text { buy at a discount, } \\
\text { otherwise they } \\
\text { could buy } \\
\text { underlying assets. }\end{array}$ & $\begin{array}{l}\text { Yes. Discount } \\
\text { is negatively } \\
\text { related to } \\
\text { institutional } \\
\text { ownership and } \\
\text { positively to } \\
\text { underlying } \\
\text { asset } \\
\text { information } \\
\text { and excess } \\
\text { fund volatility } \\
\end{array}$ \\
\hline $\begin{array}{l}\text { Gemmill \& } \\
\text { Thomas (2002) }\end{array}$ & UK & $\begin{array}{l}158 \mathrm{UK} \\
\text { funds } \\
\text { with } \\
\text { matching } \\
\text { open-end } \\
\text { equivalen } \\
\text { ts }\end{array}$ & 1991-1997 & $\begin{array}{l}\text { Discounts are the } \\
\text { result of noise- } \\
\text { trader and } \\
\text { arbitrageur } \\
\text { interplay. Changes } \\
\text { in discount are a } \\
\text { function of noise } \\
\text { trader demand. } \\
\text { Arbitrage costs and } \\
\text { expenses drive the } \\
\text { level of the } \\
\text { discount. }\end{array}$ & $\begin{array}{l}\text { Yes. Mutual } \\
\text { fund flows } \\
\text { proxy for noise } \\
\text { trader } \\
\text { sentiment. } \\
\text { Uses F\&C to } \\
\text { look at } \\
\text { retail/institutio } \\
\text { nal ownership. }\end{array}$ \\
\hline
\end{tabular}

Vol. 12, No. 4 
Accounting and Management Information Systems

\begin{tabular}{|c|c|c|c|c|c|}
\hline Author & $\begin{array}{c}\text { Sample } \\
\text { origin }\end{array}$ & $\begin{array}{c}\text { Sample } \\
\text { size }\end{array}$ & $\begin{array}{l}\text { Sample } \\
\text { period }\end{array}$ & $\begin{array}{c}\text { Explanation } \\
\text { examined }\end{array}$ & $\begin{array}{c}\text { Findings } \\
\text { confirmatory }\end{array}$ \\
\hline $\begin{array}{l}\text { Burch et al. } \\
(2003)\end{array}$ & US & \begin{tabular}{|l|}
393 \\
closed- \\
end funds
\end{tabular} & $\begin{array}{l}\text { Sep } 8 \\
2000-\text { Oct } \\
312001\end{array}$ & $\begin{array}{l}\text { Discounts worsen } \\
\text { severely following } \\
\text { unpredictable } \\
\text { "Nine-Eleven" } \\
\text { reflecting small } \\
\text { investor sentiment }\end{array}$ & Yes \\
\hline \begin{tabular}{|l} 
Doukas \& \\
Milonas (2004)
\end{tabular} & Greece & \begin{tabular}{|l|}
16 \\
closed- \\
end funds
\end{tabular} & $1997-2002$ & $\begin{array}{l}\text { Discount is } \\
\text { measure of investor } \\
\text { sentiment and } \\
\text { relates to small } \\
\text { stock returns but } \\
\text { not industrial } \\
\text { factors }\end{array}$ & No \\
\hline $\begin{array}{l}\text { Hughen \& } \\
\text { McDonald } \\
(2005)\end{array}$ & US & \begin{tabular}{|l|}
22 \\
domestic \\
closed- \\
end \\
funds.
\end{tabular} & $\begin{array}{l}\text { Jan-Dec } \\
1999 . \\
\text { Daily } \\
\text { trading } \\
\text { data }\end{array}$ & $\begin{array}{l}\text { Discount changes } \\
\text { are influenced by } \\
\text { institutional trades, } \\
\text { not individual } \\
\text { trades. }\end{array}$ & Yes. \\
\hline $\begin{array}{l}\text { Agyei-Ampomah } \\
\text { \& Davies (2005) }\end{array}$ & UK & \begin{tabular}{|l|}
210 \\
funds \\
with over \\
15 \\
months \\
data
\end{tabular} & $1970-1998$ & $\begin{array}{l}\text { Fund returns are } \\
\text { less volatile than } \\
\text { US fund returns } \\
\text { because of } \\
\text { predominance of } \\
\text { institutional } \\
\text { investors }\end{array}$ & $\begin{array}{l}\text { No. Confirms } \\
\text { US findings. } \\
\text { Big funds and } \\
\text { domestic funds } \\
\text { especially } \\
\text { volatile }\end{array}$ \\
\hline Copeland (2007) & UK & $\begin{array}{l}133 \\
\text { closed- } \\
\text { end } \\
\text { funds. }\end{array}$ & 1990-2004 & $\begin{array}{l}\text { Discount is mean- } \\
\text { reverting }\end{array}$ & Yes \\
\hline $\begin{array}{l}\text { Cherkes et al. } \\
(2008)\end{array}$ & US & \begin{tabular}{|l|}
658 \\
funds \\
includes \\
bond and \\
equity \\
funds \\
\end{tabular} & 1986-2006 & $\begin{array}{l}\text { Sentiment does not } \\
\text { influence the } \\
\text { discount. Liquidity } \\
\text { does. }\end{array}$ & $\begin{array}{l}\text { Partial. Finds } \\
\text { more support } \\
\text { for liquidity } \\
\text { than sentiment. }\end{array}$ \\
\hline Flynn (2011) & US & $\begin{array}{l}458 \text { stock } \\
\& \text { bond } \\
\text { funds }\end{array}$ & $1985-2001$ & $\begin{array}{l}\text { US closed-end } \\
\text { funds more volatile } \\
\text { than UK closed- } \\
\text { end funds }\end{array}$ & $\begin{array}{l}\text { Yes, but not } \\
\text { clear whether } \\
\text { this is because } \\
\text { of institutional } \\
\text { investors or } \\
\text { nature of } \\
\text { sample. }\end{array}$ \\
\hline $\begin{array}{l}\text { Gemmill \& } \\
\text { Thomas (2011) }\end{array}$ & UK & $\begin{array}{l}75 \\
\text { continuo } \\
\text { usly }\end{array}$ & $1988-2007$ & $\begin{array}{l}\text { Arbitrage cap } \\
\text { causes discount in } \\
\text { UK and US. }\end{array}$ & Yes. \\
\hline
\end{tabular}




\begin{tabular}{||l|l|l|l|l|l||}
\hline Author & $\begin{array}{c}\text { Sample } \\
\text { origin }\end{array}$ & $\begin{array}{l}\text { Sample } \\
\text { size }\end{array}$ & $\begin{array}{c}\text { Sample } \\
\text { period }\end{array}$ & \multicolumn{1}{|c||}{$\begin{array}{c}\text { Explanation } \\
\text { examined }\end{array}$} & $\begin{array}{c}\text { Findings } \\
\text { confirmatory }\end{array}$ \\
\hline & $\begin{array}{l}\text { traded } \\
\text { UK equity } \\
\text { funds } \\
34 \text { US } \\
\text { equity } \\
\text { funds }\end{array}$ & $\begin{array}{l}\text { Modified by } \\
\text { rational factors in } \\
\text { the UK and } \\
\text { behavioral factors } \\
\text { in the US }\end{array}$ & \\
\hline Hwang (2011) & US & $\begin{array}{l}19 \text { closed } \\
\text {-end } \\
\text { country } \\
\text { funds } \\
\text { from 15 } \\
\text { countries }\end{array}$ & $1993-2008$ & $\begin{array}{l}\text { Sentiment is related } \\
\text { to the discount of } \\
\text { specific country } \\
\text { funds. This can be } \\
\text { estimated in } \\
\text { various ways }\end{array}$ & Yes \\
\hline
\end{tabular}

\subsection{Investor Sentiment and Closed-end Funds}

The central anomaly of closed-end funds is the fluctuating difference between the share price and the value of the underlying assets (Net Asset Value or NAV). Much research has been devoted to the concept of investor sentiment (primarily in the US) and its possible role as an explanation of the in the closed-end fund puzzle. The two key articles addressing this issue are those of De Long et al. (1990) and Lee et al., (1991). Lee et al. (1991) build on the article by De Long et al. (1990) in which the concept of 'noise trader sentiment' is applied to closed-end funds. The argument of Lee et al. (1991) is based on the assumption that closed-end funds attract both informed and uninformed investors. Uninformed investors have expectations that are not based on fundamental value and are influenced by 'noise' instead of news (Black 1986). These uninformed investors form the dominant clientele group of the fund but not of the underlying assets. Their unpredictable optimism or pessimism affects the share price and poses a systematic risk to informed investors who will generally only invest in discounted funds to compensate for this risk. Lee et al. (1991) regress changes in the discount with returns on in New York Stock exchange firms owned by retail or small investors and find support for the influence of small investor sentiment. They further argue that the concept of investor sentiment can explain why trusts are launched at a premium which subsequently declines, why discounts fluctuate and why they disappear at open-ending. The closed-end fund debate seemed to be solved.

However, Chen et al. (1993) rejected the argument made by Lee et al. (1991). They questioned the economic significance of the results and found no strong relationship between small firm returns and the closed-end fund discount, regardless of the percentage of institutional ownership within the funds. The resulting exchange of views in the Journal of Finance polarized the closed-end fund debate into a rationality versus sentiment debate, reflecting the wider on-going division in asset pricing, while the issues raised in the exchange were addressed in 
other studies. Using the same sample as Lee et al. (1991), Brauer (1993) using another measure finds that only $7 \%$ of the variance in weekly discount changes is due to noise trader activity. Swaminathan (1996) also does research on the same sample and also finds a common variation between the closed-end fund discount and small firm excess returns but finds that this relates to rational expectations about future expected return and inflation rather than to irrational investor sentiment. Elton et al. (1998) using a larger sample, also cast doubt on another of the predictions of Lee et al. (1991): the ability of discount changes to predict stock returns.

However, there were also several studies supporting the findings of Lee et al. (1991). Pontiff (1995) for example, finds support for both rational and investor sentiment theories in the ability of the premium to predict future share price returns. This feature had already been observed by Thompson (1978). Pontiff (1997) attributes most of the excess volatility he observes to irrational investor sentiment, as does Brown (1999) who finds support for a relation between investor sentiment and excess closed-end fund volatility. Neal and Wheatley (1998) find, supporting the findings of Lee et al. (1991) that the closed-end fund discount is a statistically significant factor in explaining small fund returns.

A fundamental assumption made by Lee et al. is that US closed-end funds are primarily held by small investors. In the UK, however, closed-end funds are mainly held by institutions that are not supposed to be prone to irrational investor sentiment, but are supposed to make rational assessments based fundamental values and informed expectation. Nonetheless, Agyei-Ampomah and Davies (2005) find that the prices of UK closed-end funds show excess volatility in relation to the net asset value. Gemmill and Thomas (2002) also argue that while investor sentiment does not cause the discount in the first place, changes in investor sentiment cause subsequent fluctuations in the discount. Gemmill and Thomas (2011) re-examine the arbitrage issue with a more recent example of UK and US funds (1988-2007). They argue that the discount in both markets persists because of arbitrage constraints and find that premiums and discounts are more influenced by rational factors (liquidity and management fees) in the UK and by investor sentiment factors (dividend payout and idiosyncratic risk) in the US.

Examining the role of institutional investors in asset pricing, and in the pricing of closed-end funds in particular, Sias (1997) finds that institutional investors are much more active in the closed-end fund market as measured by their trades, than a simple ownership statistic would imply. He also finds no evidence that institutional investors face systematic noise trader risk or are offsetting the positions of individual investors as argued in Lee et al. (1991). In a further study of the role of noise traders in the pricing of closed-end funds, Sias et al. (2001) finds no evidence to support the hypothesis of De Long et al. (1990) that the owners of closed-end funds earn superior returns to the owners of underlying assets as a compensation for bearing noise trader risk. 
A slightly different approach is taken by Grullon and Wang (2001) who develop a model to account for the discount based on an informed ownership hypothesis (i.e. institutional ownership) which they scale by the quality of private information. They find that the discount is negatively related to the institutional ownership differential because institutional arbitrageurs are attracted to high discount funds; the discount is positively related to the quality of private information in the underlying assets, because institutional investors would prefer to invest in the underlying assets and will only invest in funds if the discount is sufficiently large. Hughen and McDonald (2005) also focus on the role of institutional investors, arguing that they are the noise traders, rather than individual investors, because their trades have the largest impact on pricing. Examining US daily trades, they find evidence that discount changes are influenced by institutional trades rather than by individual trades.

Several papers criticize the finding by Lee et al. (1991) that the discount predicts returns on small stocks. Doukas and Milonas (2004) apply the same tests as Lee et al. (1991) on a sample of Greek closed-end funds between 1997 and 2002 and find support for the findings of Elton et al. (1998). They find that sentiment does not enter into the return generating process for small stocks. Qiu and Welch (2006) also find this and show that the US closed-end fund discount does not correlate with other measures of sentiment. Studies which find support for the impact of sentiment in the stock market, however, and use the closed-end fund discount as a sentiment proxy include those by Brown and Cliff (2005), developing the earlier work by Brown (1999); Lemmon \& Portniaguina (2006); Baker \& Wurgler (2006), Baker \& Wurgler (2007) and Baker et al. (2012).

Cherkes et al. (2009) compare sentiment and liquidity as explanations of the closed-end fund discount. Cherkes et al. (2009) develop a model in which premiums and discounts reflect a trade-off between liquidity benefits and management fees. They also conduct an empirical analysis in which they advance the hypothesis that liquidity plays more of a role in the discount than sentiment. They use two measures of sentiment: the Michegan Sentiment Index and the S\&P volatility index (VIX). They conduct a three stage regression and find more support for their liquidity hypothesis than for sentiment.

\subsection{Country Funds and Sentiment}

Bodurtha et al. (1995) suggest that closed-end country funds are excellent for testing the theory of investor sentiment because there are two sets of investors: the local (foreign) investor and the international (US) investor. Thus, analyzing the discount in country funds shows the influence of two sources of investor sentiment more clearly than by analyzing the discount of US domestic funds, as the fund and the underlying assets of domestic funds may be influenced by similar investor sentiment. Bodurtha et al. (1995) suggest that country fund premium fluctuations 
reflect the sentiment of small investors who are likely to be over-optimistic or over-pessimistic in their assessment of the fundamental share value, resulting in premiums or discounts. In this way the premium or discount captures the difference in sentiment between the US and foreign market. Basing their models on the earlier research of Lee et al. (1991) and De Long et al. (1990), Hardouvelis et al. (1994) and Bodurtha et al. (1995) find evidence to support this noise-trader model in relation to country funds. Frankel and Schmukler (1996) on the other hand, take a rational perspective, arguing that unexpectedly large premiums, such as those that occurred during the Mexican crisis of 1994, are due to information asymmetries between local and US investors causing them to value shares differently. This interpretation is developed further in Chandar and Patro (2000). However, Kramer and Smith (1998) disagree with Frankel and Schmukler (1996), suggesting instead that loss-averse US investors were hanging on to shares which had lost net asset value during the Mexican crisis and this created the large premiums.

A more recent study of the impact of information asymmetries is carried out by Chen et al. (2009) who examine the differences in sophistication between US and Taiwanese closed-end fund investors. They find that when Taiwanese closed-end funds announce that they are open-ending, the Taiwanese investors sell their shares and fail to profit from the rise of the share price to NAV which occurs at openending. Foreign investors in Taiwanese closed-end funds hold on to their shares, however and make a profit at open-ending.

Another way of examining sentiment is to carry out event studies and to study price changes around the time of newsworthy events. Klibanoff et al. (1998) find a relationship between prominently featured news items and the pricing of closedend funds, supporting the investor sentiment hypothesis. This kind of event study was also carried out by Burch et al. (2003) when they looked at the impact of the attack on the Twin Towers in 2001 on the US closed-end fund discount. They make the point that research often relies on 'joint tests that discounts contain sentiment and that sentiment predicts security returns' (p527) and avoid this problem by looking at the impact of an unpredictable external event on the pricing of closed-end funds. A more recent study is that of Hwang (2011) who constructs a country popularity score based on Gallup surveys of public opinion and finds evidence to relate the discount fluctuations of specific funds to particular events, such as German reunification and the Iraq war.

\section{LIQUIDITY-BASED EXPLANATIONS}

Table 2 summarizes the findings of key papers on liquidity and closed-end funds. 
Table 2. Liquidity Studies

\begin{tabular}{|c|c|c|c|c|c|}
\hline Author & \begin{tabular}{|c|} 
Sample \\
origin
\end{tabular} & $\begin{array}{c}\text { Sample } \\
\text { size }\end{array}$ & $\begin{array}{l}\text { Sample } \\
\text { period }\end{array}$ & Explanation examined & $\begin{array}{c}\text { Findings } \\
\text { confirmatory? }\end{array}$ \\
\hline $\begin{array}{l}\text { Chordia } \\
(1996)\end{array}$ & US & $\begin{array}{l}13 \text { closed- } \\
\text { end } \\
\text { and } \\
\text { open-end } \\
\text { funds }\end{array}$ & 1984-1993 & $\begin{array}{l}\text { Mainly examines open-end } \\
\text { funds, but also argues that } \\
\text { closed-end funds are likely } \\
\text { to hold more illiquid assets } \\
\text { than open-end funds due to } \\
\text { lack of redemption rights }\end{array}$ & $\begin{array}{l}\text { Not significant } \\
\text { perhaps because } \\
\text { of small sample of } \\
\text { closed-end funds }\end{array}$ \\
\hline $\begin{array}{l}\text { Datar } \\
(2001)\end{array}$ & US & $\begin{array}{l}18 \\
\text { domestic } \\
\text { equity } \\
90 \text { bond } \\
\text { funds }\end{array}$ & 1988-1991 & \begin{tabular}{|lrr} 
Discounts & arise & when \\
underlying & assets & more \\
liquid than & shares. Also due \\
to & diversification \\
disadvantage &
\end{tabular} & Yes \\
\hline $\begin{array}{l}\text { Deli \& } \\
\text { Varma } \\
(2002)\end{array}$ & US & $\begin{array}{l}472 \text { funds } \\
\text { including } \\
\text { bond and } \\
\text { equity } \\
\text { funds }\end{array}$ & \begin{tabular}{|l|}
$1997-1998$ \\
\end{tabular} & $\begin{array}{l}\text { The liquidity and } \\
\text { transparency of assets } \\
\text { influences the choice } \\
\text { of whether the fund is open } \\
\text { or closed-end }\end{array}$ & $\begin{array}{l}\text { Yes. Funds with } \\
\text { less liquidity and } \\
\text { transparency are } \\
\text { more likely to be } \\
\text { closed-end funds }\end{array}$ \\
\hline $\begin{array}{l}\text { Manzler } \\
(2005)\end{array}$ & US & $\begin{array}{l}20 \\
\text { domestic } \\
\text { funds }\end{array}$ & $1995-2003$ & $\begin{array}{l}\text { Discount increases when } \\
\text { fund becomes less liquid and } \\
\text { when liquidity risk increases }\end{array}$ & Yes \\
\hline $\begin{array}{l}\text { Cherkes } \\
\text { et al. } \\
(2009)\end{array}$ & US & $\begin{array}{l}658 \text { funds } \\
\text { including } \\
\text { bond and } \\
\text { equity } \\
\text { funds }\end{array}$ & $1986-2006$ & $\begin{array}{l}\text { Discount and premiums arise } \\
\text { from trade off between fees } \\
\text { and liquidity benefit to small } \\
\text { investors }\end{array}$ & $\begin{array}{l}\text { Not strong } \\
\text { empirical support }\end{array}$ \\
\hline $\begin{array}{l}\text { Chan, } \\
\text { Jain \& } \\
\text { Xia } \\
(2008)\end{array}$ & US & $\begin{array}{l}41 \\
\text { country } \\
\text { funds }\end{array}$ & $1987-2001$ & $\begin{array}{l}\text { Relative market illiquidity } \\
\text { explains part of the variation } \\
\text { in CECF discount }\end{array}$ & $\begin{array}{l}\text { Yes. Strong } \\
\text { empirical support }\end{array}$ \\
\hline
\end{tabular}

In one of the early studies of closed-end funds, Malkiel (1977) finds that investing in restricted stock is one reason funds may sell at a discount, reflecting the illiquidity of such stock. Lee et al. (1991) dismiss the idea of the illiquidity of restricted stock as a general explanation of the discount, observing that discounts also occur with many large funds that do not invest in restricted stock. They argue that this may show that investors do not believe that the stock has been sufficiently discounted and are therefore only prepared to buy the fund at a discount.

\subsection{Illiquidity as a Factor in the Cost of Arbitrage}

A related line of argument is that the discount exists because of mispricing which is due to market frictions. Arbitrageurs would normally make the appropriate 
investment decisions to reduce this mispricing. Thus, if a closed-end fund is selling at a discount to the market value of the underlying stock (NAV) the arbitrageurs could short sell the underlying stock and buy the share in the closed-end fund which in theory would force the two together. There may be barriers that prevent this process, however. Pontiff (1996) argues that barriers to arbitrage may include the following: the security's unique risk may make it difficult to hedge; high interest rates may present a barrier as short sales may not provide arbitrageurs with full interest; various transaction costs may be a barrier; and a low dividend income may be another barrier since dividends lower holding costs. In his multifactor model Pontiff relates these potential barriers to the size of the deviation of the stock price from the NAV. He does not investigate how these factors might cause a discount as opposed to a premium, but instead evaluates the absolute size of the deviation from the NAV.

Pontiff (1996) observes that country funds have more variable discounts than domestic funds and argues that this is because they are expensive to hedge. Arbitrage is more expensive for these funds than for funds investing in domestic securities because of the higher transaction costs when trading the foreign securities required for hedging such funds. He does not explain why arbitrage issues could cause the premiums observed in foreign funds rather than the discount, or his observation that the Germany Fund was selling at a $13 \%$ premium while the Future Germany Fund was selling at an $11 \%$ discount, when the transaction costs presumably were similar as the stocks were in the same market.

Gemmill and Thomas (2002), following Pontiff (1996), argue that the discount persists as the costs of arbitrage are usually too high to make arbitrage profitable. They distinguish the origins of the discount from fluctuations in the discount, which they attribute to the activities of noise traders. In general, Gemmill and Thomas find that that funds which are small and not easy to replicate have higher discounts because they are more costly to arbitrage. Gemmill and Thomas (2002) take issue with the liquidity argument (the argument that the discount arises because of the uncertainty surrounding the value of the underlying assets) arguing that Draper and Paudyal (1991) did not find a significant effect in the UK. ${ }^{3}$ Gemmill and Thomas also argue that because the share price rises to the net-asset value both in the UK and the US on open-ending, as found by Brauer (1984), (1988), Draper (1989) and Minio-Paluello (1998) overstatement of the NAV is not an issue.

\subsection{Liquidity as a Key Explanation}

Papers which deal with liquidity as a key issue for closed-end funds include those by Deli and Varma (2002), Datar (2001), Cherkes et al. (2009) and Manzler (2005). Deli and Varma (2002) focus on the advantages and disadvantages of the closed-end and open-end fund structure. They argue that firms choose the closed- 
end form because it offers liquidity advantages. If the firm wishes to invest in illiquid stock where the price is less established, it is more likely to choose the closed-end form. With the closed-end form the firm does not have to redeem shares, which is an advantage if it holds illiquid stock. Open-end firms will invest in stock with more liquid assets with transparent prices which are more readily redeemable if required. The closed-end form is therefore particularly suited to firms investing in foreign securities as they face various potential costs. The first of these costs for are the higher transaction costs for foreign securities which are less frequently traded than domestic securities. An open-end fund could incur more transaction costs as the fund has to stand ready to redeem shares when required by investors. Following Lee et al. (1991) Deli and Varma (2002) also suggest that changes in investor sentiment are more likely to affect funds that invest in foreign securities and that the closed-end form protects the firm from having to redeem shares when the area is no longer popular. Deli and Varma also argue that having to trade in the redemption of foreign shares is more costly where there is more possibility for firms to create value by discretionary trading. And finally they contend, following Malkiel (1977) and Lee et al. (1991) that the closed-end form is more suited for investment in foreign securities as they are difficult to value.

Their findings support the earlier work of Chordia (1996) who presents a model showing that the more likely it is that a fund will have to redeem shares, the more liquid the holdings invested in by the fund. This means that closed-end funds are in the position to hold more illiquid assets.

Cherkes et al. (2009), building on earlier work by Cherkes (2003), make a substantial theoretical contribution to liquidity-based explanations of closed-end funds. Like Deli and Varma (2002) they suggest that there are specific advantages to the closed-end form. Cherkes et al. further argue that closed-end funds offer small investors a liquidity benefit for which they are prepared to pay an IPO premium, which is then traded off against the fees charged by the fund managers. They argue that 'in the absence of fees, funds will trade at a premium, in the presence of fees it will trade at a discount or premium depending on the size of fees relative to the liquidity benefit' (Cherkes et al., 2009, p. 258). This paper develops Cherkes' previous clientele argument (Cherkes, 2003) in which he argues that closed-end funds are aimed at distinct clientele groups. He identifies one such group as consisting of those who wish to invest overseas but lack the opportunities to invest in such countries.

Cherkes et al. (2009) develop a formal model of the tradeoff between liquidity and management fees which they calibrate using a US dataset. They use two measures for the liquidity premium: the Roll trading cost measure and Pastor and Stambaugh's reversal measure. They argue that their explanation is superior to the sentiment explanation of the closed-end fund puzzle advocated by others such as Zweig (1973), De Long et al. (1990) and Lee et al. (1991). 
Their model is intuitively appealing. There are some issues which it does not address, however. One issue is that it is based on the assumption that most of the investors in closed-end funds are small investors. In countries such as the UK, however, most of the investors in closed-end funds are institutional investors. It is not clear therefore why liquidity should be a sufficient motivator for an institution to be prepared to pay a premium to invest in a closed-end fund. Most institutional investors will have sufficient funds to make large investments and thereby to achieve less costly transactions than the individual investor. However, Cherkes (2012) argues that although the investors may be large, the size of their investments is generally small. ${ }^{44}$

Datar (2001) argues that closed-end fund discounts and premiums result from liquidity differences between the closed-end fund and the underlying assets. When the fund share is more liquid than the assets, a premium will result; when the underlying assets are more liquid, a discount will result. Datar's study lacks the spread of other studies as he restricts himself to analyzing the weekly returns of 18 US domestic equity funds and 90 bond funds over a four year period from January 1988 to December 1991 (Datar 2001).

As predicted, Datar (2001) finds that the premium increases (discounts decrease) as fund liquidity increases, as estimated by the volume of trade, dollar volume of trade and turnover rate. He suggests that a basket (fund) is less sensitive to private information than its contents but also potentially increases transaction costs due to reduced trading, to the extent that informed traders do not trade the basket but only some of its contents. Whether there is a premium or a discount depends on which predominates. Datar suggests that stock funds are more likely to have higher discounts than bond funds because of the higher underlying asymmetry of information in stock funds. To find more evidence that liquidity affects the price of closed-end fund shares, Datar (2001) looks at least traded stocks and closed-end funds to identify if they are driven by a common factor, following the analysis of Lee et al. (1991) who carry out a similar test with small stocks and find a sentiment effect. Datar finds that the lowest decile (comprising the least traded stocks) has the strongest relationship with excess returns realized by the closed-end industry.

Manzler (2005) examines the role of liquidity in the discount of 20 US domestic closed-end funds between 1995 and 2003. Manzler extends the work of Datar (2001) in that as well as looking at the liquidity effect, he also looks at liquidity risk. He finds a significant relationship between the discount and the difference in liquidity between the fund share and the underlying assets: when the fund is less liquid than the assets, the discount increases. He also finds that when the liquidity risk of the closed-end fund becomes greater in relation to the underlying assets, the discount increases. 
Chan et al. (2008) suggest that relative market illiquidity explains part of the variation in closed-end country fund discount. If capital markets are segmented it follows that the closed-end country fund premium will be positively affected by the illiquidity of the underlying assets but negatively affected by share price illiquidity. In other words, US investors will pay a higher share price to invest in less liquid markets, such as emerging markets, which are not easily accessible for direct investment.

Like Manzler (2005), Chan et al. (2008) use the Amihud (2002) illiquidity measure which is constructed using daily market returns and volume. This paper assumes that the liquidity of the underlying assets can be proxied by the liquidity of the foreign market as a whole - an assumption criticized by Manzler (2005). The control variables used are the following: expense ratio, size, age, dividend yield, institutional ownership, a measure of capital control (Edison \& Warnock 2003), market risk factor in the share market, market risk factor in the asset market, foreign exchange appreciation rate and the average fund premium as a proxy for investor sentiment. The main finding of the study is that the closed-end fund premium is significantly positively related to foreign market illiquidity, but significantly negatively related to fund illiquidity.

Davies et al. (2013) also examine the role of country and fund illiquidity in the context of UK country funds. Their findings support those of Chan et al. (2008) in a larger more recent UK sample with different share ownership. In addition they examine the liquidity impact of the 2008 financial crisis on UK closed-end funds and the markets in which they invest. They find that the developed market fund discount increases significantly during the crisis, whereas the emerging market fund discount shows an insignificant increase. The reason for this difference, they suggest, is because investors were seeking to sell the shares of funds in developed markets which were more rapidly affected by the crisis than emerging markets.

Ramadorai (2012) analyses hedge funds as they are a type of closed-end fund, albeit with important differences. He finds evidence to support the impact of liquidity, sentiment, managerial skills and compensation, but not of sentiment on the premium of closed hedge funds between 1998 and 2008. He then uses these findings to draw implications for other closed-end funds.

\section{SEGMENTATION-BASED EXPLANATIONS}

Table 3 summarizes the findings of key papers on market segmentation and closedend funds. 
Table 3. Segmentation Studies

\begin{tabular}{|c|c|c|c|c|c|}
\hline Author & $\begin{array}{l}\text { Sample } \\
\text { origin }\end{array}$ & Sample size & $\begin{array}{c}\text { Sample } \\
\text { period }\end{array}$ & $\begin{array}{c}\text { Explanation } \\
\text { examined }\end{array}$ & $\begin{array}{c}\text { Findings } \\
\text { confirmatory? }\end{array}$ \\
\hline \begin{tabular}{|l|} 
Bonser- \\
Neal et al. \\
$(1990)$
\end{tabular} & US & $\begin{array}{l}33 \text { domestic } \\
\& 14 \text { country } \\
\text { funds }\end{array}$ & 1981-1989 & $\begin{array}{l}\text { Premiums arise } \\
\text { when closed-end } \\
\text { fund is unique } \\
\text { investment } \\
\text { vehicle into } \\
\text { restricted country }\end{array}$ & Partially \\
\hline $\begin{array}{l}\text { Chang } \\
\text { et al. } \\
(1995)\end{array}$ & US & $\begin{array}{l}15 \text { country } \\
\text { funds with } \\
2 \text { year } \\
\text { trading } \\
\text { history }\end{array}$ & $1985-1990$ & $\begin{array}{l}\text { Segmentation } \\
\text { effect. Examine } \\
\text { co-integration of } \\
\text { prices and NAVs. } \\
\text { Examine } \\
\text { performance } \\
\text { relative to MSCI } \\
\text { and potential } \\
\text { diversification } \\
\text { benefit }\end{array}$ & $\begin{array}{l}\text { Partially. Emerging } \\
\text { fund prices and NAVs } \\
\text { not co-integrated so } \\
\text { potential diversification } \\
\text { benefit. Find only one } \\
\text { fund outperforms. }\end{array}$ \\
\hline $\begin{array}{l}\text { Choi } \\
\& \text { Lee } \\
(1996) \\
\end{array}$ & US & $\begin{array}{l}21 \text { country } \\
\text { funds }\end{array}$ & $1978-1990$ & $\begin{array}{l}\text { Premiums reflect } \\
\text { restrictions but } \\
\text { also other factors }\end{array}$ & Partially \\
\hline $\begin{array}{l}\text { Bekaert } \\
\& \text { Urias } \\
(1996)\end{array}$ & US/UK & \begin{tabular}{|l|}
43 US \\
country \\
funds \& \\
37 UK funds \\
(single \\
country \& \\
diversified)
\end{tabular} & 1986-1993 & $\begin{array}{l}\text { Closed-end } \\
\text { country funds } \\
\text { provide } \\
\text { diversification } \\
\text { benefits as } \\
\text { compared with } \\
\text { IFC investable } \\
\text { indices. Effect of } \\
\text { liberalization on } \\
\text { diversification } \\
\text { benefit. }\end{array}$ & $\begin{array}{l}\text { Yes for UK emerging } \\
\text { market funds. Not for } \\
\text { comparable US funds. } \\
\text { Only } 1 \text { of } 4 \text { emerging } \\
\text { market countries } \\
\text { showed reduced } \\
\text { diversification benefit } \\
\text { after liberalization. }\end{array}$ \\
\hline \begin{tabular}{|l|} 
Errunza et \\
al. $(1998)$
\end{tabular} & US & $\begin{array}{l}32 \text { closed- } \\
\text { end country } \\
\text { funds. }\end{array}$ & 1993-1994 & $\begin{array}{l}\text { Returns on funds } \\
\text { are affected by } \\
\text { global market, } \\
\text { restrictions on } \\
\text { capital flows and } \\
\text { availability of } \\
\text { substitutes. Lack } \\
\text { of substitutes and } \\
\text { capital restrictions } \\
\text { increase the } \\
\text { premium. }\end{array}$ & $\begin{array}{l}\text { Find significant } \\
\text { influence of access and } \\
\text { global factor in } \\
\text { emerging market funds. } \\
\text { Global factor in } \\
\text { developed market } \\
\text { funds. }\end{array}$ \\
\hline \begin{tabular}{|l|} 
Frankel \& \\
Schmukler \\
$(2000)$
\end{tabular} & US & $\begin{array}{l}3 \text { Mexican } \\
\text { closed-end } \\
\text { funds }\end{array}$ & $1990-1996$ & $\begin{array}{l}\text { Premiums during } \\
\text { the Mexican crisis } \\
\text { of } 1994 \text { were }\end{array}$ & $\begin{array}{l}\text { Yes. They find that } \\
\text { NAVs fell more } \\
\text { quickly than prices and }\end{array}$ \\
\hline
\end{tabular}


Liquidity, sentiment and segmentation: a survey of closed-end fund literature

\begin{tabular}{|c|c|c|c|c|c|}
\hline Author & $\begin{array}{c}\text { Sample } \\
\text { origin } \\
\end{array}$ & Sample size & $\begin{array}{l}\text { Sample } \\
\text { period }\end{array}$ & $\begin{array}{c}\text { Explanation } \\
\text { examined }\end{array}$ & $\begin{array}{c}\text { Findings } \\
\text { confirmatory? }\end{array}$ \\
\hline & & & & $\begin{array}{l}\text { caused by } \\
\text { Mexicans selling } \\
\text { shares before } \\
\text { international } \\
\text { investors. }\end{array}$ & $\begin{array}{l}\text { that NAVs granger- } \\
\text { cause the price } \\
\text { movement. }\end{array}$ \\
\hline $\begin{array}{l}\text { Chandar } \\
\text { \& Patro } \\
(2000)\end{array}$ & US & $\begin{array}{l}25 \text { currency } \\
\text { crises, } \\
18 \text { funds }\end{array}$ & $1988-1997$ & $\begin{array}{l}\text { Premiums during } \\
\text { crises are caused } \\
\text { by a differential in } \\
\text { risk exposure } \\
\text { between the NAV } \\
\text { and the share } \\
\text { price. }\end{array}$ & $\begin{array}{l}\text { Yes. They find that } \\
\text { NAVs are more } \\
\text { sensitive to a local } \\
\text { market drop in value, } \\
\text { whereas the share price } \\
\text { reacts less as it is more } \\
\text { strongly related to } \\
\text { global market } \\
\text { movement. }\end{array}$ \\
\hline $\begin{array}{l}\text { Levy- } \\
\text { Yeyati \& } \\
\text { Ubide } \\
(2000)\end{array}$ & US & $\begin{array}{l}24 \text { single } \\
\text { country } \\
\text { funds }\end{array}$ & 1994-1998 & $\begin{array}{l}\text { Premiums during } \\
\text { country crises } \\
\text { reflect } \\
\text { information } \\
\text { asymmetry } \\
\text { between home and } \\
\text { foreign investors. }\end{array}$ & $\begin{array}{l}\text { Yes. Premiums in crisis } \\
\text { countries increase, but } \\
\text { decrease in other } \\
\text { emerging market } \\
\text { countries due to US } \\
\text { investor risk aversion. }\end{array}$ \\
\hline $\begin{array}{l}\text { Patro } \\
(2001)\end{array}$ & US & $\begin{array}{l}45 \text { single } \\
\text { country } \\
\text { funds }\end{array}$ & 1991-1997 & $\begin{array}{l}\text { Examines } \\
\text { performance of } \\
\text { funds using a } \\
\text { range of measures } \\
\text { compared to } \\
\text { world market and } \\
\text { local market } \\
\text { indices }\end{array}$ & $\begin{array}{l}\text { Neither share price nor } \\
\text { NAV outperforms local } \\
\text { market or world market } \\
\text { indices. }\end{array}$ \\
\hline $\begin{array}{l}\text { Eun et al. } \\
(2002)\end{array}$ & & & & $\begin{array}{l}\text { Theoretical paper. } \\
\text { Argues that } \\
\text { country fund } \\
\text { premiums and } \\
\text { discounts arise } \\
\text { from differences } \\
\text { in demand in the } \\
\text { home and host } \\
\text { countries for the } \\
\text { underlying assets. }\end{array}$ & \\
\hline $\begin{array}{l}\text { Lee \& } \\
\text { Hong } \\
(2002)\end{array}$ & US & $\begin{array}{l}33 \text { single } \\
\text { country } \\
\text { funds }\end{array}$ & 1995-1999 & $\begin{array}{l}\text { Argue that closed- } \\
\text { end country } \\
\text { funds provide an } \\
\text { effective means of } \\
\text { diversification as } \\
\text { their returns are }\end{array}$ & $\begin{array}{l}\text { Use a VAR framework } \\
\text { to analyze returns to } \\
\text { closed-end country } \\
\text { funds and find evidence } \\
\text { for their hypothesis. }\end{array}$ \\
\hline
\end{tabular}

Vol. 12, No. 4 


\begin{tabular}{|c|c|c|c|c|c|}
\hline Author & $\begin{array}{c}\text { Sample } \\
\text { origin }\end{array}$ & Sample size & $\begin{array}{c}\text { Sample } \\
\text { period }\end{array}$ & $\begin{array}{c}\text { Explanation } \\
\text { examined }\end{array}$ & $\begin{array}{c}\text { Findings } \\
\text { confirmatory? }\end{array}$ \\
\hline & & & & $\begin{array}{l}\text { more related to } \\
\text { the foreign market } \\
\text { than the US } \\
\text { market. }\end{array}$ & \\
\hline $\begin{array}{l}\text { Nishiotis } \\
(2004)\end{array}$ & US & $\begin{array}{l}10 \text { emerging } \\
\text { market } \\
\text { closed-end } \\
\text { funds }\end{array}$ & 1989-2001 & $\begin{array}{l}\text { Indirect barriers as } \\
\text { well as direct } \\
\text { barriers to } \\
\text { investment play a } \\
\text { role in emerging } \\
\text { market fund } \\
\text { premium. }\end{array}$ & $\begin{array}{l}\text { Generally } \\
\text { confirmatory. Find } \\
\text { contradictory evidence } \\
\text { when he reruns tests of } \\
\text { Bonser-Neal } \text { et al. } \\
(1990)\end{array}$ \\
\hline $\begin{array}{l}\text { Patro } \\
(2005)\end{array}$ & US & $\begin{array}{l}\text { All } 34 \\
\text { emerging } \\
\text { market } \\
\text { country } \\
\text { funds }\end{array}$ & 1981-1999 & $\begin{array}{l}\text { Examines } \\
\text { implications of } \\
\text { Errunza, Senbet \& } \\
\text { Hogan applied to } \\
\text { larger more recent } \\
\text { sample. }\end{array}$ & $\begin{array}{l}\text { Like Errunza et al } \\
(1998) \text { does not find } \\
\text { support for loosening } \\
\text { of restrictions on } \\
\text { premium but does on } \\
\text { NAV at } 10 \% \text { and on } \\
\text { share price at lesser } \\
\text { effect. He finds support } \\
\text { for sensitivity of } \\
\text { premiums to } \\
\text { announcements of new } \\
\text { funds. }\end{array}$ \\
\hline $\begin{array}{l}\text { Nishiotis } \\
(2006)\end{array}$ & US & $\begin{array}{l}17 \text { closed- } \\
\text { end country } \\
\text { funds }\end{array}$ & 1989-1996 & $\begin{array}{l}\text { Examines the } \\
\text { relation between } \\
\text { the closed-end } \\
\text { fund premium and } \\
\text { international } \\
\text { capital flows. }\end{array}$ & $\begin{array}{l}\text { Yes. Finds evidence of } \\
\text { segmentation in most } \\
\text { of the emerging } \\
\text { markets with some } \\
\text { becoming less } \\
\text { segmented over time. }\end{array}$ \\
\hline $\begin{array}{l}\text { Jones \& } \\
\text { Stroup } \\
(2010)\end{array}$ & US & $\begin{array}{l}26 \text { closed- } \\
\text { end country } \\
\text { funds }\end{array}$ & $2000-2006$ & $\begin{array}{l}\text { Hypothesis is that } \\
\text { closed-end fund } \\
\text { premiums and } \\
\text { discounts reduce } \\
\text { as economic } \\
\text { freedom increases. }\end{array}$ & $\begin{array}{l}\text { Yes. Finds that funds } \\
\text { investing in countries } \\
\text { with greater economic } \\
\text { freedom have smaller } \\
\text { discounts and } \\
\text { premiums. } \\
\end{array}$ \\
\hline $\begin{array}{l}\text { Kim \& } \\
\text { Song } \\
(2010)\end{array}$ & US & $\begin{array}{l}55 \text { closed- } \\
\text { end country } \\
\text { funds }\end{array}$ & $1995-2004$ & $\begin{array}{l}\text { Argues that } \\
\text { indirect } \\
\text { investment } \\
\text { barriers are } \\
\text { associated with } \\
\text { increased } \\
\text { premiums. }\end{array}$ & $\begin{array}{l}\text { Yes. Finds that indirect } \\
\text { investment barriers are } \\
\text { associated with } \\
\text { increased premiums } \\
\text { and after market } \\
\text { liberalization relation } \\
\text { between premium and } \\
\text { country risk increases. }\end{array}$ \\
\hline
\end{tabular}




\subsection{Market Liberalization and the Discount}

In the key early paper on segmentation and the closed-end country fund discount, Bonser-Neal et al. (1990) argue that discounts and premiums on country funds are related to the investment restrictions operating in the foreign market. Their hypothesis is that when investment restrictions are loosened, the premium should fall because the closed-end country fund is no longer a unique vehicle for investment. If capital markets are already integrated, however, there should be no effect on the discount if restrictions are loosened. They also argue that closed-end country funds are good for testing segmentation because they avoid the joint hypothesis problem which arises when using an asset pricing model to test segmentation.

Bonser-Neal et al. (1990) compare the discount between 33 domestic and 14 country funds between May 1981 and January 1989 and find generally smaller discounts in country funds. Next they examine a smaller group of 5 closed-end country funds and relate investment restriction announcements to discount fluctuations. They find some evidence that as markets become less restrictive, the discount increases. However, their sample of country funds is limited to five funds, three of which invest in segmented markets, and the evidence from the Taiwan fund does not support the hypothesis.

Choi and Lee (1996) take issue with the study of Bonser-Neal et al (1990) and point out that one fund that invests in a restricted market may trade at a discount whereas another fund investing in a restricted market may trade at a premium. They suggest that this implies that there are also factors particular to each country, such as economic factors, that may influence discounts and premiums.

Choi and Lee (1996) examine closed-end country fund pricing and what determines the fund share price return in a partially segmented capital market. They regress weekly closed-end country fund returns against weekly US market returns in a 2 factor model where the factors are the local and US markets. Their study contributes in that they look at funds cross-sectionally as well as over time and they introduce three degrees of restriction instead of the tightening/loosening distinction of Bonser-Neal et al. (1990). However, they only have 2 emerging market funds whose returns are significantly related only to local market return, whereas the remaining 9 emerging market funds are significantly related to both US and local market returns (7) or none (2).

\subsection{Diversification Benefits}

If markets are segmented and have low correlations with one another, this implies, following Solnik (1974), that a portfolio containing investments in countries with low correlations will be highly diversified and that risk will be reduced. Several papers that address market segmentation in closed-end country funds do so with the 
aim of determining whether closed-end funds offer a diversification benefit. Chang et al. (1995) find evidence of segmentation in emerging markets in that the prices and NAVs of emerging market funds are not co-integrated, whereas the prices and NAVs of developed market funds are co-integrated. Bailey and Lim (1992) in a shorter study also examine the diversification benefits of closed-end country funds and conclude from their examination of correlations between the New York Index and various country funds, that they are indeed generally highly correlated and that to achieve diversification benefits ideally one should invest directly in the foreign stock market.

Bekaert and Urias (1996) also consider the benefits of diversification using UK and US emerging market closed-end country funds as compared with International Finance Corporation (IFC) Investable indices. They measure diversification benefits relative to a set of mature market benchmark returns. Their main finding is that UK emerging market funds provide diversification benefits that are statistically significant, but that US funds which are comparable do not provide such benefits. They suggest that this difference may be due more to differences in portfolio selection, but this is not investigated in the study. In the spirit of Bonser-Neal et al. (1990) they also examine the impact of liberalizations for Brazil, India, Korea and Taiwan using their spanning methodology. They find that only in the case of Taiwan did the opening of the market significantly reduce the diversification benefit it provided.

The study by Patro (2001) is similar in approach to that of Chang et al. (1995) and Bekeart and Urias (1996). Patro (2001) compares the performance of closed-end country funds with the US market index, but does not find that the closed-end country funds outperformed the US index.

\subsection{Information Asymmetries}

Some papers focus on the response of the closed-end country fund premium to a crisis in the country in which the fund invests. Frankel and Schmukler (1996) analyze the Mexican crisis of 1994 and find large premiums in funds investing in Mexico. They argue that these large premiums are caused by information asymmetries which cause US and local investors to value shares differently. Levy-Yeyati and Ubide (2000) also find that closed-end country fund premiums increase dramatically during crises. Decomposing the premium into movements in the NAV and share price, they find that the reason for the high premiums is that local investors react more quickly to the local crisis, causing the NAV to fall quickly, whereas US investors react more slowly, causing the share price to decrease less than the NAV which gives rise to premiums. They also argue that changes in world market conditions are more likely to affect the share price than the NAV and find a significant negative relation between changes in fund premiums and variations in the MSCI, and a significant positive relation between changes in fund premiums and local market indices. 
This interpretation is developed further in Chandar and Patro (2000). They show that the premiums and the volatility of the premiums of emerging market funds (and to a lesser extent of developed market funds) show a dramatic increase at times of currency crises and that these increases only correct themselves slowly over time. They argue that this is the result of the fact that the NAV and the share price of closed-end fund have different risk exposure with the NAV being more sensitive to changes in the local market index and the share price being more sensitive to movement in the global market. At a time of currency crisis, this difference causes the NAV to react quickly to the drop in value of the local market, while the share price reacts more slowly, due to its global sensitivity.

Errunza et al. (1998) argue that several factors affect country fund premiums. Key amongst them are the level of access foreign investors have to the country; the extent to which the securities can be substituted by securities displaying similar characteristics in the home country; and the influence of the global market. They find significant support for a global factor in the premium of both emerging and developed market funds. They also examine the extent to which the country fund price return is explained by the country (domestic) market factor, a US factor and a global country fund index which captures noise trading across all funds. They find that this global market factor correlates clearly with country fund returns even in the presence of the US and local markets. Errunza et al. (1998) discuss the policy implications of their findings. They suggest that closed-end country funds should be invested in local assets which do not have substitutes in the home market, such as natural resources; they also argue that the introduction of country funds can improve pricing efficiency in emerging markets and that therefore international agencies may wish to introduce measures to stabilize country fund prices.

Somewhat similar in approach to Errunza et al. (1998) is the theoretical paper by Eun et al. (2002). In this paper they use a framework of market equilibrium in international markets when there are investment barriers. They suggest that country fund premiums and discounts arise from differences in demand in the home and host countries for substitutable securities. If the fund has as many securities as are required by the difference in demand for substitutable securities between the home and foreign investor, then the fund will have neither a discount nor a premium.

Patro (2005) further extends the work of Errunza et al. (1998) by empirically examining the implications of their paper in more detail on a new and larger set of country funds. He examines the effect of the market liberalization announcements to premiums, prices and NAVs. He also examines the effect of the announcement of new funds has on the premium of existing funds in the same country. The key finding of the paper is that the country fund premiums decrease by over $8 \%$ when a new fund is announced, supporting the spanning argument of Errunza et al. (1998). Again, like Errunza et al. (1998) he does not find support for the effect of loosening of investment restrictions on the premium, but finds support for a global 
fund factor in the price and premium of country funds. He argues that the reason liberalization does not affect the premium is because while the NAV increases significantly (at $\mathrm{t} 10 \%$ ) the share price also increases in response to the change in the NAV, causing no major impact on the premium.

While many papers focus on explaining the closed-end country fund premium, Lee and Hong (2002) examine the impact of the home and foreign market in explaining the returns on closed-end country funds. Although similar in spirit to the paper by Bodurtha et al. (1995) the paper by Lee and Hong differs in that it uses a VAR framework to analyze the impact of US market returns, exchange rate returns, local market returns in the local currency and closed-end country fund returns. In their more recent sample they find, unlike Bodurtha, Kim and Lee, that the returns of closed-end country funds are less influenced by US market returns than by the returns in the foreign market they invest in. This implies that the funds are providing a diversification benefit to investors.

\subsection{Investment Barriers Revisited}

Nishiotis (2004) revisits the hypothesis of Bonser-Neal et al. (1990) that the country fund discount is related to investment restrictions. Nishiotis argues that there are indirect barriers to investment as well as direct barriers, particularly in emerging markets, and that these influence the pricing of closed-end funds. $\mathrm{He}$ suggests that this can explain why some emerging market country fund premiums drop when direct barriers are lifted but other emerging market country fund premiums do not drop. Using proxies to estimate market illiquidity, political risk and macroeconomic instability, he finds evidence broadly consistent with the hypothesis that indirect investment barriers affect closed-end country fund premiums. He reruns the tests of Bonser-Neal et al. (1990) on his sample and finds conflicting evidence. He argues that the lack of relationship between the announcement and premium is due to the influence of political and macroeconomic events at the time i.e. indirect investment barriers.

Returning to the theme of the closed-end country fund premium and investment barriers, Nishiotis (2006) looks at the relation between international capital flows from the US Treasury and the closed-end country fund premium. He suggests that increases in capital flows indicate that the barriers are lessening and will lead to a reduction in the premium as investors react negatively to a reduction in the diversification benefit. He finds a relation between international capital flows and the closed-end country fund premium in eight out of seventeen markets. He finds that while most developed countries are not segmented, most emerging countries are segmented with some becoming less segmented over time.

Froot and Ramadorai (2008) use cross-border portfolio flows into open and closedend funds to proxy for the impact of informed investor behavior and uninformed 
'price pressure' activity respectively. They find evidence that closed-end fund flows predict fund share price returns but not NAV returns and conclude that closed-end fund flows are more strongly related to short-term price pressure whereas institutional flows across borders are more linked to changes in fundamentals, supporting an information hypothesis.

In a more recent paper in the framework of information asymmetry, Chen et al. (2013) find a positive relation between the discount of country funds and the earnings opacity of the companies in which the fund invests. They suggest that a higher discount corresponds to a greater degree of difficulty in acquiring and evaluating information on the underlying assets, as US investors are less willing to pay more when they are more uncertain of the value of their investment.

Chan et al. (2008) (discussed above) suggest that segmentation plays a role in the discount. They focus mainly on market and fund illiquidity as the source of part of the variation in the country fund premium. If capital markets are segmented, they argue, it follows that the country fund premium will be positively affected by asset illiquidity but negatively affected by share price illiquidity. Although their paper focuses on the illiquidity argument, they use the Edison Warnock (2003) measure of capital control as one of their control variables. This measure is the ratio of the value of the market that is accessible to foreign investors to the global value of the market. They find that over their sample period (1987-2001) capital control measures are significantly positively related to the premium, supporting the hypothesis of Bonser-Neal et al. (1990).

Jones and Stroup (2010) highlight a problem in previous studies that look at the relation between investment barriers and the closed-end country fund premium: the choice of barriers. They avoid making this choice by using the Fraser Institute Economic Freedom Index measure which comprises both direct and indirect investment barriers. They test the hypothesis that the greater the economic freedom becomes, the more the discounts and premiums will reduce, as market frictions should reduce as a result of greater market integration. The results of their regressions provide some evidence to support their hypothesis.

Kim and Song (2010) argue that the effect of the direct barriers on the premium should be weaker in the post-liberalization period. They therefore examine the period 1995-2004, the post-liberalization period, and find that indirect barriers have a stronger impact on the closed-end fund premium, whereas direct barriers, proxied by the Standard and Poor's Investable Weight Factor, do not have a significant impact on the premium. One drawback of this study is that because it uses annual data, like that of Jones and Stroup (2010), it has less descriptive power than the other papers in this area. 


\section{CONCLUSION}

This paper surveys the literature on closed-end funds with a particular emphasis on three alternative factors that might explain the widely documented premium/discount: sentiment, liquidity and segmentation. There is a substantial body of work on the role of individual investor sentiment, although the issue of quantifying investor sentiment continues to be problematic. There is general agreement in the literature that the closed-end structure facilitates investment in less liquid assets and less liquid markets. There is less agreement, however, on the role of market segmentation in the pricing of closed-end funds. Again the estimating of market segmentation, such as the choice of direct and indirect investment barriers, is a contested issue. Future research may move beyond seeking to explain the closed-end fund discount towards considering the advantages and disadvantages of the closed-end structure applied to other areas; we also expect to see research that uses the dual pricing of closed-end funds to shed light on the way in which market asymmetries and frictions affect pricing in different markets.

\section{REFERENCES}

Agyei-Ampomah, S. \& Davies, J.R. (2005) "Excess volatility and UK investment trusts", Journal of Business Finance and Accounting, vol. 32, no. 5: 1033-1061

Amihud, J. (2002) "Illiquidity and stock returns: cross-section and time series effects", Journal of Financial Markets, vol. 5, no. 1: 31-56

Bailey, W. \& Lim, J. (1992) "Evaluating the diversification benefits of the new country funds", Journal of Portfolio Management, vol. 18, no. 3: 74-80

Baker, M. \& Wurgler, J. (2006) "Investor sentiment and the cross-section of stock returns", Journal of Finance, vol. 61, no. 4: 1645-1680

Baker, M. \& Wurgler, J. (2007) "Investor sentiment in the stock market", Journal of Economic Perspectives, vol. 21, no. 2: 129-151

Baker, M., Wurgler, J. \& Yuan, Y. (2012) "Global, local and contagious investor sentiment", Journal of Financial Economics, vol. 104, 272-287

Bekaert, G. \& Urias, M. S. (1996) "Diversification, integration and emerging market closed-end funds", Journal of Finance, vol. 51, no. 3: 835-869

Black, F. (1986) "Noise", Journal of Finance, vol. 41, no. 3: 529-543

Bodurtha, J. N., Kim, D.-S. \& Lee, C. M. (1995) "Closed-end country funds and US market sentiment", The Review of Financial Studies, vol. 8, no. 3: 879-918

Bonser-Neal, C., Brauer, G., Neal, R. \& Wheatley, S. (1990) "International investment restrictions and closed-end country fund prices", Journal of Finance, vol. 45 , no. 2: 523-547

Brauer, G. (1993) ""Investor sentiment" and the closed-end fund puzzle: a 7 percent solution", Journal of Financial Services Research, 199-216

Brauer, G. A. (1984) "'Open-ending' closed-end funds", Journal of Financial Economics, vol. 13: 491-507 
Brauer, G. (1988) "Closed-end fund shares abnormal returns and the information content of discounts and premiums", Journal of Finance, vol. 43, no. 1: 113-127

Brown, G. W. (1999) "Volatility, sentiment and noise traders", Financial Analysts Journal, vol. 55 , no. 2: 82-90

Brown, G. W. \& Cliff, M. T. (2005) "Investor sentiment and asset valuation", Journal of Business, vol. 78, no. 2: 405-440

Burch, T. R., Emery, D. R. \& Fuerst, M. E. (2003) "What can "nine-eleven" tell us about closed-end fund discounts and investor sentiment?", The Financial Review, vol. 38: 515-529

Chan, J. S., Jain, R. \& Xia, Y. (2008) "Market segmentation, liquidity spillover, and closed-end country fund discounts", Journal of Financial Markets, vol. 11, no. 4: 377-399

Chandar, N. \& Patro, D. K. (2000) "Why do closed-end country funds trade at enormous premiums during currency crises?", Pacific-Basin Finance Journal, vol. $8: 217-248$

Chang, E., Eun, C. S. \& Kolodny, R. (1995) "International diversification through closed-end country funds", Journal of Banking and Finance, vol. 19: 1237-1263

Chen, F., Hope, O.-K., Li, Q. \& Wang, X. (2013, March) "Earnings opacity and closed-end country fund discounts", Working Paper, University of Toronto

Chen, L.-W., Johnson, S. A., Lin, J.-C. \& Liu, Y.-J. (2009) "Information, sophistication and foreign versus domestic investors' performances", Journal of Banking and Finance, vol. 33: 1636-1651

Chen, N.-F., Kan, R. \& Miller, M. (1993) "Are the discounts on closed-end funds a sentiment index?", Journal of Finance, vol. 48, no. 2: 795-800

Cherkes, M. (2003) "A positive theory of closed-end funds as an investment vehicle", Working paper, Princeton University

Cherkes, M. (2012) "Closed-end funds: a survey", Annual Review of Financial Economics, vol. 4: 431-445

Cherkes, M., Sagi, J. \& Stanton, R. (2009) "A liquidity-based theory of closed-end funds", Review of Financial Studies, vol. 22, no. 1: 257-297

Choi, J. J. \& Lee, I. (1996) "Market segmentation and the valuation of closed-end country funds: an empirical analysis", Review of Quantitative Finance and Accounting, vol. 7: 45-63

Chordia, T. (1996) "The structure of mutual fund charges", Journal of Financial Economics, vol. 41: 3-39

Copeland, L. (2007) "Arbitrage bounds and the time series properties of the discount on UK closed-end funds", Journal of Business Finance and Accounting, vol. 34, nos. 1\&2: 313-330

Datar, V. (2001) "Impact of liquidity on premia/discounts in closed-end funds", Quarterly Review of Economics and Finance, vol. 41: 119-135

Davies, J. R., Fletcher, M. \& Marshall, A. (2013) "Investigating the role of illiquidity in explaining the UK closed-end country fund discount", International Review of Financial Analysis, vol. 30: 121-130 
De Long, B., Shleifer, A., Summers, L. \& Waldemann, R. (1990) "Noise trader risk in financial markets", Journal of Political Economy, vol. 98, no. 4: 703-738

Deli, D. N. \& Varma, R. (2002) "Closed-end versus open-end: the choice of organizational form", Journal of Corporate Finance, vol. 8: 1-27

Dimson, E. \& Minio-Kozerski, C. (1999) "The closed-end fund discount and performance persistence", Working paper, London Business School

Doukas, J. A. \& Milonas, N. T. (2004) "Investor sentiment and the closed-end fund discount: out of sample evidence", European Financial Management, vol. 10, no. 2: 235-266

Draper, P. (1989) "The investment trust industry in the UK: an empirical analysis", Aldershot: Gower Press

Draper, P. \& Paudyal, K. (1991) "The investment trust discount revisited", Journal of Business Finance and Accounting, vol. 18, no. 6: 791-805

Edison, H. J. \& Warnock, F. E. (2003) "A simple measure of the intensity of capital controls", Journal of Empirical Finance, vol. 10: 81-103

Elton, E. J., Gruber, M. J. \& Busse, J. A. (1998) "Do investor care about sentiment?", Journal of Business, vol. 71, no. 4: 477-500

Errunza, V., Senbet, L. W. \& Hogan, K. (1998) "The pricing of country funds from emerging markets: theory and evidence", International Journal of Theoretical and Applied Finance, vol. 1, no. 1: 111-143

Eun, C. S., Janakiramanan, S. \& Senbet, L. W. (2002) "The pricing of emerging market country funds", Journal of International Money and Finance, vol. 21: $833-855$

Flynn, S. M. (2012) "Noise-trading, costly arbitrage, and asset prices: evidence from US closed-end funds", Journal of Financial Markets, vol. 15, no. 1: 108-125

Frankel, J. \& Schmukler, S. (1996) "Country fund discounts, asymmetric information, and the Mexican crisis of 1994: Did locals turn pessimistic before international investors?", NBER Working Paper 5714, Berkeley, CA: University of California

Froot, K.A. \& Ramadorai, T. (2008) "Institutional portfolio flows and international investments", Review of Financial Studies, vol. 21, no. 2: 937-971

Gemmill, G. \& Thomas, D. C. (2011) "Arbitrage, idiosyncratic risk and the rationality of discounts on closed-end funds", Working paper, University of Warwick

Gemmill, G. \& Thomas, D. C. (2002) "Noise trading, costly arbitrage and asset prices: evidence from closed-end funds", Journal of Finance, vol. 57, no. 6: 2571-2593

Grullon, G. \& Wang, F. A. (2001) "Closed-end funds with informed ownership differential", Journal of Financial Intermediation, vol. 10: 171-205

Hardouvelis, G. A., LaPorta, R. \& Wizman, T. A. (1994) "What moves the discount of country equity funds? in J. Frankel (Ed.), The Internationalization of Equity Markets. Chicago: University of Chicago Press

Hughen, J. C. \& McDonald, C. G. (2005) "Who are the noise traders?", Journal of Financial Research, vol. 28, no. 2: 281-298 
Hwang, B.-H. (2011) "Country-specific sentiment and security prices", Journal of Financial Economics, vol. 100: 382-401

Jones, S.K. \& Stroup, M. D. (2010) "Closed-end country fund premiums and economic freedom", Applied Financial Economics, vol. 20: 1639-1649

Kim, J.-C. \& Song, K. R. (2010) "Investment barriers and premiums on closed-end country funds", International Review of Economics and Finance, vol. 19: 615-626

Klibanoff, P., Lamont, O. \& Wizmann, T. A. (1998) "Investor reaction to salient news in closed-end country funds", Journal of Finance, vol. 53, no. 2: 673-699

Kramer, C. \& Smith, T. (1998) "The Mexican crisis and the behavior of country fund discounts: Renewing the puzzle of closed-end fund pricing", International Journal of Theoretical and Applied Finance, vol. 1: 161-174

Lee, B.-S. \& Hong, G. (2002) "On the dual characteristics of closed-end country funds", Journal of International Money and Finance, vol. 21: 589-618

Lee, C. M., Shleifer, A. \& Thaler, R. H. (1991) "Investor sentiment and the closedend fund puzzle", Journal of Finance, vol. 46, no. 1: 75-109

Lemmon, M. \& Portniaguina, E. (2006) "Consumer confidence and asset prices", Review of Financial Studies, vol. 19, no. 4: 1499-1521

Levy-Yeyati, E. \& Ubide, A. (2000) "Crises, contagion and the closed-end country fund puzzle", IMF Staff Papers, vol. 47, no. 1: 54-89

Malkiel, B. G. (1977) "The valuation of closed-end investment company shares", Journal of Finance, vol. 32, no. 3: 847-899

Manzler, D. (2005) "Liquidity, liquidity risk and the closed-end fund discount", Working paper, University of Cincinnati College of Business

Minio-Paluello, C. (1998) "The UK Closed-End Fund Discount", PhD thesis, London Business School

Neal, R. \& Wheatley, S. M. (1998) "Do measures of investor sentiment predict returns?", Journal of Financial and Quantitative Analysis, vol. 33, no. 4: 523-547

Nishiotis, G.P. (2004) "Do indirect investment barriers contribute to capital market segmentation”, Journal of Financial and Quantitative Analysis, vol. 39, no. 3: 613-630

Nishiotis, G. P. (2006) "Further evidence on closed-end country fund prices and international capital flows", Journal of Business, vol. 79, no. 4: 1727-1754

Patro, D. K. (2001) "Measuring performance of international closed-end funds", Journal of Banking \& Finance, vol. 25, no. 9: 1741-1767

Patro, D. K. (2005) "Stock market liberalization and emerging market country fund premiums", Journal of Business, 78: 135-168

Pontiff, J. (1995) "Closed-end fund premia and return implications for financial market equilibrium", Journal of Financial Economics, vol. 37: 341-370

Pontiff, J. (1996) "Costly arbitrage: evidence from closed-end funds", The Quarterly Journal of Economics, vol. 111, no. 4: 1135-1151

Pontiff, J. (1997) "Excess volatility and closed-end funds", American Economic Review, vol. 87: 155-169 
Qiu, L. \& Welch, I. (2006) "Investor sentiment measures", Working paper, Brown University and NBER

Ramadorai, T. (2012) "The secondary market for hedge funds and the closed hedge fund premium", Journal of Finance, vol. 67, no. 2: 479-512

Sias, R. (1997) "Price pressure and the role of institutional investors in closed-end funds", Journal of Financial Research, vol. 20, no. 2: 211-229

Sias, R. W., Starks, L. T. \& Tinic, S. M. (2001) "Is noise trader risk priced?", Journal of Financial Research, vol. 24, no. 3: 311-329

Solnik, B. (1974) "Why not diversify internationally rather than domestically?", Financial Analysts Journal, vol. 30, no. 4: 48-52 + 54

Swaminathan, B. (1996) "Time-varying expected small firm returns and closed-end fund discounts", Review of Financial Studies, vol. 9, no. 3: 845-887

Thompson, R. (1978) "The information content of discounts and premiums on closed-end fund shares", Journal of Financial Economics, vol. 6: 151-186

Zweig, M. E. (1973) "An investor expectations stock price predictive model using closed-end fund premiums", The Journal of Finance, vol. 28: 67-87

${ }^{1}$ The Net Asset Value is the total value of the fund's assets, i.e. the value of the shares invested in by the fund, minus all of the fund's liabilities.

${ }^{2}$ The premium is the difference between the fund share price and the NAV, divided by the NAV. This is usually expressed as a percentage. Following the practice of Bodurtha et al. (1995) and Chan et al. (2008), we use the term premium to refer to both the case where the share price is above the NAV and where it is lower than the NAV (a negative premium or discount). Where required by the context, for example when discussing the work of other authors, we also use the term discount.

${ }^{3}$ In their 1991 paper Draper and Paudyal conclude that it is not likely that valuation issues are very important.

${ }^{4}$ The author thanks Martin Cherkes for pointing this out. 